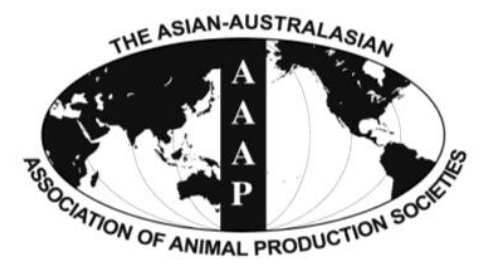

Asian-Aust. J. Anim. Sci.

Vol. 25, No. 4 : 559 - 568

April 2012

www.ajas.info

http://dx.doi.org/10.5713/ajas.2011.11382

\title{
Effects of Rearing Systems on Performance, Egg Characteristics and Immune Response in Two Layer Hen Genotype
}

\author{
Kamil Küçükyılmaz*, Mehmet Bozkurt, Emine Nur Herken ${ }^{1}$, Mustafa Çınar, \\ Abdullah Uğur Çatlı, Erol Bintaş and Fethiye Çöven ${ }^{2}$ \\ ${ }^{1}$ Erbeyli Poultry Research Institute, İncirliova/Aydın, Turkey
}

\begin{abstract}
White (Lohmann LSL) and Brown (ATAK-S) laying hens, were reared under organic and conventional cage rearing systems, and the effects of the rearing system on performance parameters, egg production, egg characteristics, and immune response were investigated. For this purpose, a total of 832 laying hens of two commercial hybrids, i.e., 416 white (Lohmann LSL) and 416 Brown (ATAK-S) layers, were used. The experiment lasted between 23 and 70 wk of age. In this study, the white layers yielded more eggs as compared to the brown layers in both organic and conventional production systems. Egg weight exhibited a similar pattern to that of laying performance. However, the total hen-housed egg number for the white birds in the organic system was fewer than that of white birds in the conventional cage facility; conversely, a contradictory tendency was observed for the brown birds. Livability of the white layers in the organic system was remarkably lower (14\%) than that of the brown line, whereas the white line survived better $(3.42 \%)$ than their brown counterparts in conventional cages. The feed conversion ratio of the white hens was markedly inferior in the organic system as compared to that of the white hens in the conventional system, whereas relatively lower deterioration was reported in brown layers when reared in an organic system. The organic production system increased egg albumen height and the Haugh unit in eggs of the brown layers. The yolk color score of organic eggs was lower than that of conventional eggs for both brown and white hens. The egg yolk ratio of eggs from white layers was found to be higher in organic eggs as compared to those obtained in the conventional system. All organic eggs had heavier shells than those produced in the conventional system. Eggs from brown layers had more protein content than eggs from white layers. Neither housing systems nor genotype influenced egg yolk cholesterol concentration. When compared to conventional eggs, n-3 fatty acid content was lower in organic eggs, and the n-6:n-3 ratio was higher in organic eggs. In conclusion, two hen genotypes showed different responses in terms of performance and egg quality to two different rearing systems. A commercial white strain produced more eggs with higher egg quality as compared to a native brown strain. The brown strain was found to have adapted well to organic production conditions when survival and total egg number was taken into consideration. (Key Words : Organic, Cage, Genotype, Laying Hen Performance, Egg Characteristics, Immune Response)
\end{abstract}

\section{INTRODUCTION}

Following the EU regulation (EU, 1999), which orders a ban on conventional battery cages in the EU starting on 1 January 2012, and also changes in consumer demand, many research and development facilities have been directed to establish alternative housing systems. This situation has resulted in the development of enriched cages, small group

\footnotetext{
* Corresponding Author : Kamil Küçükyılmaz. Tel : +90-256-581 1123, Fax : +90-256-5811124, E-mail : kamilkucukyilmaz@ hotmail.com

${ }^{1}$ Department of Food Engineering, Faculty of Engineering, Pamukkale University, Denizli, Turkey.

${ }^{2}$ Bornova Veterinary Control and Research Institute - İzmir, Turkey.

Submitted Oct. 21, 2011; Accepted Dec. 28, 2011; Revised Jan. 2, 2012
}

systems, and barn and aviary systems. Independent from those approaches, rearing laying hens under organic conditions has evolved as a novel production system during the last decade.

Organic egg production is based on specific and precise standards (EU, 2007) and this farming procedure is progressively increasing. Briefly, organic eggs can be defined as the product of a rearing system which absolutely avoids conventionally grown feedstuffs including GMO (genetically modified organisms or crops), animal byproducts, and synthetic additives; only organically grown cereals, oil seeds, and roughage is fed and the birds are given free access to outdoor areas, which lower rearing intensity and certain stresses.

Consumers believe organic eggs to be more tasty, more nutritious, and safer than conventionally produced eggs, 
even though there is no firm and consistent evidence available in the scientific literature (Kouba, 2003). Therefore, consumers are willing to pay more for organically produced eggs compared to conventional ones. Organic eggs are expected to have better egg quality compared to conventional ones due to the hens free access to outdoor life and organic feed consumption. Based on the increasing public interest in organic hen eggs, some studies recently have shown the effects of different housing systems on egg quality (Cerolini et al., 2005; Rizzi et al., 2006; Minelli et al., 2007; Rossi, 2007).

As outdoor systems become increasingly important, their effects on performance indices and egg quality need to be clear. Hen performance, nutritional composition and external quality of table eggs are affected not only by the rearing system but also various other factors such as breed and age of the hen, feed ingredient composition, and nutrient density of the diet (Cerolini et al., 2005; Rizzi et al., 2006; Minelli et al., 2007; Rossi, 2007; Mugnai et al., 2009). Previous studies have shown that alternative rearing systems could affect some quality features and nutritional composition of eggs (Lopez-Bote et al., 1998; Van Den Brand et al., 2004; Basmacioğlu and Ergül, 2005). A significant rearing system by genotype interaction was also found in another study pertaining to performance and egg quality (Basmacioğlu and Ergül, 2005). Even though an increasing number of studies during recent years have investigated the effect of organic rearing system on performance traits and egg quality (Cherian et al., 2002; Cerolini et al., 2005; Rizzi et al., 2006; Minelli et al., 2007; Rossi, 2007; Mugnai et al., 2009; Samman et al., 2009), there has been little research concerning characteristics of current commercial hen genotypes (Rizzi and Chiericato, 2005). In addition, it is important for producers and consumers to be informed about the effects of organic rearing on the nutritional composition and quality of eggs. The objective of our study was to investigate the effects of 2 housing systems (cage and organic) and layer genotype (white and brown) on laying performance, egg quality, egg components, and immune response of layer hens.

\section{MATERIALS AND METHODS}

\section{Animals, housing and feeding}

A total of 832 laying hens of two commercial hybrids, 416 white (Lohmann LSL) and 416 brown (ATAK-S) layers at 23 wk of age, were used in this study. Hens of both genotype were reared according to their corresponding growth procedure from 1 to 22 wk of age. After weighing hens individually at the end of the $22 \mathrm{wk}$ of age, the average body weight was calculated immediately for each rearing system of both strains. Meanwhile, the heaviest and smallest birds (i.e., the outliers) were eliminated from the treatments without creating a deviation from the original average data.

The trial was carried out through a 1 year period between January 2008 and November 2008 under subtropics conditions in the Southern Aegean region of Turkey. These two genotypes were housed in both conventional cages and an organic rearing system. The experiment was arranged in $2 \times 2$ factorial design with 2 layer genotypes and 2 rearing systems.

In the conventional rearing system, 216 hens in each genotype were randomly assigned to 6 replications in tripledeck battery cages that were provided with linear feeders and nipple drinkers. Each replication consisted of 6 cages (36 hens per replication) and the hens of 6 adjacent cages were considered as a replication. Hens were kept in cages (50 cm length, $60 \mathrm{~cm}$ width, $56 \mathrm{~cm}$ height) with 6 hens per cage providing $500 \mathrm{~cm}$ floor space per bird. Hens were housed in an open-sided naturally ventilated layer house.

In the organic rearing unit, 200 white hens and 200 brown hens were randomly divided into 4 replications which were located $100 \mathrm{~m}$ away from the conventional cage barn. Housing with $10 \mathrm{~m}^{2}$ enclosed floor pen (all-litter) shelter and $200 \mathrm{~m}^{2}$ outdoor sections $\left(4 \mathrm{~m}^{2} / \mathrm{bird}\right)$ were available for each replication. Wood shavings were spread at $6 \mathrm{~cm}$ height throughout the concrete floor. The organic rearing unit was established on land consisting of a total surface area of $1,680 \mathrm{~m}^{2}$ which had 8 adjacent parcels each occupying a space of $210 \mathrm{~m}^{2}$. The pens located in the center of the parcels were made of insulated aluminum panels on an iron frame and windows were placed along one side of the house to allow daylight into the house. The indoor space $\left(5 \mathrm{bird} / \mathrm{m}^{2}\right.$ ) was furnished with 2 circular hanging feeders, a bell drinker, a three-tier perch $(30 \mathrm{~cm} / \mathrm{bird})$, and a 12-hole nest box. Two drinkers and 2 perches were available in the outdoor area too. Since the natural grassland, including alfalfa and trifolium mixture, had been depleted prior to the commencement of the trial, no vegetation was available for consumption in the outdoor area throughout the experimental period (from 23 to $70 \mathrm{wk}$ of age). The popholes were open all day, giving free access to the outdoor area all the time throughout the experiment.

Feed and drinking water was available on an ad libitum basis. The light schedule was similar in both systems with $16 \mathrm{~h}(06: 00$ to $22: 00 \mathrm{~h})$ light and $8 \mathrm{~h}$ dark. The beaks of all birds in the organic rearing system remained intact; they had been trimmed in the conventional system at $9 \mathrm{~d}$ of age.

Experimental feed mixtures used in the organic and conventional systems were prepared with corn, wheat, soybean meal, and sunflower meal. Similar ingredients were used when formulating diets in order to avoid discrepancies in ingredient and nutrient compositions between 2 systems. As established by EC Regulation $834 / 2007$ (2007), at least $90 \%$ of dry matter content of 
organic feed mixture was provided from organically grown ingredients. Sunflower meal was the only conventional feed ingredient supplemented to the organic feed mixture at an inclusion level of $10 \%$. Alfalfa meal, consisting of dried whole plant which was grown under organic farming conditions was added to the organic feed as a roughage source. Chemical compositions of ingredients and feed mixtures were analyzed according to AOAC (1995), and metabolic energy of those was calculated according to Anonymous (1991). Ingredient composition and fatty acid composition of feed mixtures are presented in Table 1 and Table 2, respectively.

\section{Experimental parameters measured}

All hens were weighted individually on the wks 23, 28, 36 , and 70 of the experiment. Egg production, broken-

Table 1. Composition and chemical analysis of the organic and conventional diets

\begin{tabular}{|c|c|c|}
\hline Ingredient & $\begin{array}{c}\text { Conventional } \\
\text { diet }(\mathrm{g} / \mathrm{kg})\end{array}$ & $\begin{array}{l}\text { Organic diet } \\
(\mathrm{g} / \mathrm{kg})\end{array}$ \\
\hline Corn & 393.33 & 330.00 \\
\hline Wheat & 234.50 & 241.21 \\
\hline Soybean meal (48\%) & 192.12 & 184.06 \\
\hline Sunflower meal (31\%) & 50.00 & 100.00 \\
\hline Alfalfa meal (18\%) & - & 25.00 \\
\hline Soybean oil & 23.31 & 11.16 \\
\hline Salt & 2.65 & 2.50 \\
\hline Ground limestone & 84.71 & 88.69 \\
\hline Dicalcium phosphate (DCP) & 14.41 & 14.88 \\
\hline Vitamin mineral premix ${ }^{1}$ & 2.50 & 2.50 \\
\hline DL-methionine & 0.97 & - \\
\hline Threonine & 0.50 & - \\
\hline Choline chloride & 0.50 & - \\
\hline Sodium bicarbonate & 0.50 & - \\
\hline Total & $1,000.00$ & $1,000.00$ \\
\hline \multicolumn{3}{|l|}{ Chemical analysis (\%) } \\
\hline Dry matter & 89.80 & 90.40 \\
\hline Crude protein & 17.65 & 17.32 \\
\hline Crude fat & 5.78 & 4.48 \\
\hline Crude fiber & 6.95 & 7.74 \\
\hline Crude ash & 12.15 & 13.35 \\
\hline Calcium & 3.82 & 3.75 \\
\hline Total phosphorus & 0.66 & 0.65 \\
\hline Metabolizable energy $(\mathrm{MJ} / \mathrm{kg})^{2}$ & 11.98 & 11.72 \\
\hline Lysine $^{2}$ & 0.70 & 0.83 \\
\hline Methionine+cysteine ${ }^{2}$ & 0.64 & 0.62 \\
\hline \multicolumn{3}{|c|}{$\begin{array}{l}{ }^{1} \text { Vitamin premix (/kg yem): Vitamin A, 12,000 IU; Vitamin } \mathrm{D}_{3}, 2,400 \mathrm{IU} \text {; } \\
\text { Vitamin E, } 30 \mathrm{IU} \text {; Vitamin } \mathrm{K}_{3}, 2.5 \mathrm{mg} \text {; Vitamin } \mathrm{B}_{1}, 3.0 \mathrm{mg} \text {; Vitamin } \mathrm{B}_{2} \text {, } \\
7.0 \mathrm{mg} \text {; nicotin amide, } 40 \mathrm{mg} \text {; Calcium D-pantothenate, } 8.0 \mathrm{mg} \text {; Vitamin } \\
\mathrm{B}_{6}, 4.0 \mathrm{mg} \text {; Vitamin } \mathrm{B}_{12}, 0.015 \mathrm{mg} \text {; Folic acid, } 1 \mathrm{mg} \text {; D-biotine, } 0.045 \\
\mathrm{mg} \text {; Choline chloride, } 125 \mathrm{mg} \text {; Mn, } 80 ; \mathrm{Fe}, 40 \mathrm{mg} \text {; Zn, } 60 \mathrm{mg} \text {; Cu, } 5 \mathrm{mg} \text {; } \\
\text { Co, } 0.1 \mathrm{mg} \text {; I, } 0.4 \mathrm{mg} \text {; Se, } 0.15 \mathrm{mg} \text {. } \\
{ }^{2} \text { Calculated composition. }\end{array}$} \\
\hline
\end{tabular}

Table 2. Fatty acid composition of organic and conventional diets

\begin{tabular}{lcc}
\hline Fatty acid (FA) & $\begin{array}{c}\text { Conventional diet } \\
(\%)\end{array}$ & $\begin{array}{c}\text { Organic diet } \\
(\%)\end{array}$ \\
\hline Palmitic C16:0 & 14.86 & 13.26 \\
Stearic C18:0 & 5.35 & 4.89 \\
Total saturated & 21.72 & 18.69 \\
Palmitoleic C16:1 & 0.16 & 0.61 \\
Oleic C18:1 & 30.18 & 27.56 \\
Total MUFA & 31.05 & 29.31 \\
Linoleic C18:2 & 43.72 & 47.39 \\
Linolenic C18:3 & 3.42 & 4.61 \\
Total PUFA & 47.14 & 52.00 \\
\hline
\end{tabular}

cracked eggs and shell-less egg were recorded daily from 23 to $70 \mathrm{wk}$ of age. During this period a random sample of 36 eggs/treatment/d was collected on two consecutive days every week (6 eggs per replicate per day for cage system, 9 eggs per replicate per day for organic system). Hence, total of 3,456 eggs were weighed to determine average egg weight throughout the trial. The feed intake and feed conversion ratio (FCR) were determined on a replicate basis at weekly intervals. FCR was expressed as kilograms of feed consumed per $\mathrm{kg}$ of egg produced. Egg mass was calculated by multiplying egg weight by egg production. The magnitude of production variables such as egg production were adjusted for hen mortalities. Death of hen was recorded daily as it occurred.

An additional sample of 24 eggs were randomly collected from each experimental group every $28 \mathrm{~d}$ to assess egg shell quality parameters. Egg shell quality characteristics were egg shell weight, egg shell strength and egg shell thickness. Egg shell thickness (without inner and outer shell membranes) was measured at three different points (top, middle, and bottom) using an ultrasonic micrometer (SANOVO Technology A/S, Odense NV, Denmark) without cracking the egg shell. Egg shell strength was measured using by electronic egg shell tester equipment (SANOVO) and expressed as unit of compression force was exposed to unit egg shell surface area $\left(\mathrm{kg} / \mathrm{cm}^{2}\right)$. Then, eggs were cracked carefully separating contents from egg shell, and albumen height was obtained using a micrometer with ultrasonic wave system (SANOVO). The same equipment also detected the yolk colour score using a RGB sensor. An average of three different thickness measurements of an egg was described as egg shell thickness. Albumen height, Haugh Unit, yolk colour, were described as internal egg quality parameters. Haugh unit was calculated using the formula described by Roush (1981).

Samples of 264 eggs of each genotype in both rearing systems which were collected 11 times with 4-wk intervals (4 eggs in cages and 6 eggs in organic pens, respectively, per replication of each examination period) throughout the 
entire trial phase, were used to determine the egg albumen ratio, egg yolk ratio, and egg shell ratio. Thus, a total of 1,056 eggs were analyzed to determine egg components between 25 to $70 \mathrm{wk}$ of hen age. Eggs which had been laid within $12 \mathrm{~h}$ were stored at room temperature for $18 \mathrm{~h}$ until analyzed. After weighing, eggs were broken onto a flat surface. Then the yolk was separated from the albumen and weighted. The shells, including membranes, were carefully separated from albumen with a paper towel, left to dry at room temperature for $2 \mathrm{~h}$, and then weighed. Albumen weight was determined by subtracting yolk and shell weights from the original egg weight. Percentage weight of egg components such as albumen, yolk, and shell were calculated by dividing their proportional weights into that whole egg weight (Novak et al., 2004).

\section{Analytical determination}

Also, a total of 48 eggs were analyzed for whole egg protein content, egg yolk cholesterol concentration, and fatty acid composition. For this purpose, random samples of 6 eggs of each genotype were collected in both housing systems at 40 wk and 68 wk of age, respectively. Egg protein content was determined according to AOAC (1995). Egg fatty acid composition was determined by gas chromatography (Agilent Technologies 6890N, Germany, 2004) according to IUPAC (1987), and presented as percentage of total fatty acids. The determination of egg yolk cholesterol concentration was performed according to AOAC (1995) by gas chromatography (Perkin Elmer Clarus 500, USA, 2003).

Blood samples were taken by puncturing the wing vein from a total of 24 birds per group at the end of the experiment (70 wk of age). Then, serum was isolated and stored at $-20^{\circ} \mathrm{C}$. Individual serum samples were analyzed for antibody responses against (IBD, NDV and IBV) by ELISA technique using commercial kits (Kirkegaard and Perry Laboratories, Gaithersburg, MD), and the plates were read at $405 \mathrm{~nm}$ on an ELISA reader (Labsystems Multiscan MS, Labsystems, Helsinki, Finland) (Shashidhara and Dewegowda, 2003).

\section{Statistical analyses}

The data was analyzed on two-way ANOVA using the general linear models (GLM) procedure found in SAS software (SAS Institute, 1995). The main effects of rearing system, genotype, and rearing system -by- genotype interaction were tested. Duncan's multiple range test was carried out to detect differences among treatments. Arc-sin transformation was applied to the percentage values before testing for differences. Significant differences were determined by using the Duncan's multiple range test with $5 \%$ probability.

\section{RESULTS AND DISCUSSION}

\section{Laying hen performance}

Data describing the effects of the rearing system and hen genotype on performance parameters and egg production characteristics are presented in Table 3 . Significant rearing system by genotype interactions $(R \times G)$ were determined for all overall performance traits either at the $\mathrm{p}<0.05$ or $\mathrm{p}<0.01$ significance level except for shell-less egg ratio. This implies that hen genotypes significantly differed in their response to different management procedures.

Egg production rate and hen-d total egg production were influenced by the hen genotype $(\mathrm{p}<0.01)$, while rearing system showed no effect on these parameters. The egg production rate of white hens was higher than that of brown hens under conditions in both rearing systems. While the egg production rate $(\%)$ and total hen-d egg production for white hens raised in an organic system was lower than that of white hens raised in a conventional system, a converse pattern was seen in brown hens. Total egg yield (i.e., both

Table 3. Influence of rearing systems on performance parameters and egg production characteristics of white and brown laying hens

\begin{tabular}{|c|c|c|c|c|c|c|c|c|}
\hline & \multicolumn{2}{|c|}{ Organic } & \multicolumn{2}{|c|}{ Conventional } & \multirow{2}{*}{ SEM } & \multicolumn{3}{|c|}{ Probability } \\
\hline & White & Brown & White & Brown & & Rearing & Genotype & $\mathrm{R} \times \mathrm{G}$ \\
\hline Egg production rate $(\%)$ & $87.23^{\mathrm{b}}$ & $82.50^{\mathrm{c}}$ & $89.82^{\mathrm{a}}$ & $80.43^{\mathrm{d}}$ & 0.34 & 0.4566 & 0.0001 & 0.0001 \\
\hline Egg weight $(g)$ & $63.43^{\mathrm{a}}$ & $62.46^{\mathrm{b}}$ & $63.11^{\mathrm{a}}$ & $61.57^{\mathrm{c}}$ & 0.13 & 0.0001 & 0.0001 & 0.0392 \\
\hline Number of total egg (Hen-d) & $299.1^{\mathrm{b}}$ & $282.9^{c}$ & $307.7^{\mathrm{a}}$ & $275.5^{\mathrm{d}}$ & 1.97 & 0.7570 & 0.0001 & 0.0008 \\
\hline Number of total egg (Hen-house) & $272.5^{\mathrm{b}}$ & $281.7^{\mathrm{b}}$ & $303.3^{\mathrm{a}}$ & $270.2^{\mathrm{b}}$ & 6.75 & 0.1737 & 0.0969 & 0.0068 \\
\hline Egg mass (g/d) & $57.00^{\mathrm{b}}$ & $53.35^{\mathrm{c}}$ & $59.01^{\mathrm{a}}$ & $50.99^{\mathrm{d}}$ & 0.66 & 0.7949 & 0.0001 & 0.0013 \\
\hline Shell-less egg $(\%)$ & $0.03^{\mathrm{b}}$ & $0.02^{\mathrm{b}}$ & $0.63^{\mathrm{a}}$ & $0.65^{\mathrm{a}}$ & 0.03 & 0.0001 & 0.4862 & 0.8316 \\
\hline Cracked-broken egg (\%) & $0.44^{\mathrm{c}}$ & $0.31^{\mathrm{c}}$ & $1.33^{\mathrm{b}}$ & $2.10^{\mathrm{a}}$ & 0.06 & 0.0001 & 0.0001 & 0.0001 \\
\hline Feed intake (g/d) & $127.69^{\mathrm{a}}$ & $127.74^{\mathrm{a}}$ & $110.18^{\mathrm{c}}$ & $114.34^{\mathrm{b}}$ & 1.01 & 0.0001 & 0.0396 & 0.0441 \\
\hline FCR (g feed/g egg) & $2.265^{\mathrm{b}}$ & $2.429^{\mathrm{a}}$ & $1.871^{\mathrm{c}}$ & $2.232^{\mathrm{b}}$ & 0.037 & 0.0001 & 0.0001 & 0.0101 \\
\hline Liveability (\%) & $85.00^{\mathrm{b}}$ & $99.00^{\mathrm{a}}$ & $96.81^{\mathrm{a}}$ & $93.39^{\mathrm{ab}}$ & 3.42 & 0.3376 & 0.1238 & 0.0265 \\
\hline
\end{tabular}

\footnotetext{
$\overline{\mathrm{a}, \mathrm{b}, \mathrm{c}, \mathrm{d}}$ Values with the different superscript are significantly different.
} 
hen-d and hen-housed) for white hens decreased by $2.87 \%$ and $11.29 \%$, respectively, in the organic system when compared to yields in the conventional system, whereas total egg yield (i.e., both hen-d and hen-housed) increased by $2.74 \%$ and $4.23 \%$, respectively, in brown hens reared in an organic system as compared to brown hens raised in a conventional system.

In agreement with our findings regarding white laying hens but in contrast to our findings with brown hens, Mugnai et al. (2009) showed that the productivity of hens in conventional rearing systems was higher than that of hens in organic systems. Our results are also in agreement with a previous report by Rizzi and Chiericato (2005) showing that commercial hybrids surpassed native hybrids in terms of egg production rate and egg mass output. Another earlier work agrees with our findings, Şekeroğlu and Sarıca (2005) reported higher egg production rates in native hybrids in cases where free range conditions were applied. Rizzi et al. (2006) reported that rearing systems had no effect on egg production.

Egg weight was significantly affected by rearing system ( $\mathrm{p}<0.05$ ), and $\mathrm{R} \times \mathrm{G}$. In accordance with the findings of the Clerici et al. (2006), an organic rearing system led to an increase in egg weight as compared to the conventional system $(p<0.01)$. Eggs from white laying hens were heavier than those of brown layer hens $(\mathrm{p}<0.01)$ from both rearing systems. In contrast to our findings, Mugnai et al. (2009) showed that the rearing system did not affect egg weight.

The cracked to broken egg ratio was significantly affected by both hen genotype and rearing system, while the shell-less egg ratio was influenced by rearing system only. The organic rearing system enhanced the characteristics that reflect eggshell quality when compared to the conventional cage procedure for both genotypes. These results concur with those reported by Mugnai et al. (2009) for the cracked to broken egg ratio. Brown laying hens produced eggs with more cracks than white layer hens in the conventional cage system. Floor laying behavior was not observed in either genotype in the organic rearing system.

The feed intake and FCR were significantly affected by rearing system $(\mathrm{p}<0.01)$, genotype $(\mathrm{p}<0.05)$, and $\mathrm{R} \times \mathrm{G}$ $(p<0.05)$. While genotypes had similar feed intakes under organic conditions, the brown layers consumed more feed (i.e., $3.77 \%$ ) than white laying hens in the conventional cage system. Brown laying hens were more active in scratching and foraging behaviors than white hens in the organic rearing system. The FCR was worse for organically reared white and brown laying hens by $21.0 \%$ and $8.8 \%$, respectively, as compared to their conventionally reared counterparts. This determination is consistent with reports from Lampkin (1997) and Castellini et al. (2004) who reported that laying hens raised in organic systems had higher feed intakes and FCR, which may have been derived from their increased motor activities. Also, our results were parallel with those of Mugnai et al. (2009).

A significant rearing system by genotype interaction was observed in terms of livability $(\mathrm{p}<0.05)$. The livability of the white hens reared in the organic system was $14 \%$ lower as compared to the brown hens reared under the same conditions, whereas the white hens survived better (i.e., by $3.42 \%$ ) than their brown counterparts in the conventional cage system. Interestingly, the deaths that were observed in one of the replicates resulted from cannibalism. This determination is consistent with the findings of some previous studies that reported a higher mortality stemming from cannibalism in organic rearing systems (Lampkin, 1997; Danish Poultry Council, 2000; Bestman and Wagenaar, 2003).

Both rearing system and genotype significantly affected body weight of hens at all age each periods examined, i.e; $23,28,36$, and $70 \mathrm{wk}$ of age $(\mathrm{p}<0.01)$. Body weight of hens in the organic system was heavier than those reared in the conventional system except at 70 wk of age. However, a converse pattern was observed in final body weight. As was expected, brown hens were heavier than white hens throughout the experimental period (Table 4).

\section{Egg quality characteristics}

Data describing the effects of rearing system and hen genotype on egg quality traits is presented in Table 5. Genotype significantly affected all egg shell quality and internal egg quality characteristics $(\mathrm{p}<0.01)$. On the other hand, the egg shape index, shell thickness, and yolk color were influenced by the conditions of the rearing system $(\mathrm{p}<0.05)$. Also, a significant rearing system by genotype interaction was observed for overall internal egg quality

Table 4. Effects of rearing systems on body weight of two layer strains

\begin{tabular}{|c|c|c|c|c|c|c|c|c|}
\hline \multirow{2}{*}{ Age (wk) } & \multicolumn{2}{|c|}{ Organic } & \multicolumn{2}{|c|}{ Conventional } & \multirow{2}{*}{ SEM } & \multicolumn{3}{|c|}{$\mathrm{p}$ value } \\
\hline & White & Brown & White & Brown & & Rearing & Genotype & $\mathrm{R} \times \mathrm{G}$ \\
\hline 23 & $1,306^{\mathrm{c}}$ & $1,619^{a}$ & $1,284^{\mathrm{d}}$ & $1,548^{\mathrm{b}}$ & 7.30 & 0.0001 & 0.0001 & 0.0007 \\
\hline 28 & $1,624^{\mathrm{c}}$ & $1,964^{\mathrm{a}}$ & $1,404^{\mathrm{d}}$ & $1,759^{b}$ & 10.12 & 0.0001 & 0.0001 & 0.4600 \\
\hline 36 & $1,756^{\mathrm{c}}$ & $2,200^{\mathrm{a}}$ & $1,690^{\mathrm{d}}$ & $2,023^{\mathrm{b}}$ & 12.99 & 0.0001 & 0.0001 & 0.0001 \\
\hline 70 & $1,702^{\mathrm{d}}$ & $2,150^{\mathrm{b}}$ & $1,820^{\mathrm{c}}$ & $2,242^{\mathrm{a}}$ & 16.36 & 0.0001 & 0.0001 & 0.4357 \\
\hline
\end{tabular}

$\overline{a, b, c, d}$ Values with the different superscript are significantly different. 
Table 5. Effects of rearing systems on egg quality traits of two layer strains

\begin{tabular}{|c|c|c|c|c|c|c|c|c|}
\hline & \multicolumn{2}{|c|}{ Organic } & \multicolumn{2}{|c|}{ Conventional } & \multirow{2}{*}{ SEM } & \multicolumn{3}{|c|}{$\mathrm{p}$ value } \\
\hline & White & Brown & White & Brown & & Rearing & Genotype & $\mathrm{R} \times \mathrm{G}$ \\
\hline Egg weight (g) & $63.32^{\mathrm{a}}$ & $62.73^{\mathrm{ab}}$ & $63.32^{\mathrm{a}}$ & $62.31^{\mathrm{b}}$ & 0.28 & 0.4612 & 0.0053 & 0.4684 \\
\hline Egg shape index & $78.14^{\mathrm{a}}$ & $78.27^{\mathrm{a}}$ & $77.46^{\mathrm{b}}$ & $77.98^{\mathrm{a}}$ & 0.14 & 0.0010 & 0.0240 & 0.1803 \\
\hline Shell thickness $(\mu)$ & $409.17^{\mathrm{a}}$ & $388.56^{\mathrm{b}}$ & $405.22^{\mathrm{a}}$ & $386.02^{\mathrm{b}}$ & 1.61 & 0.0447 & 0.0001 & 0.6594 \\
\hline Shell breaking strength $\left(\mathrm{g} / \mathrm{cm}^{2}\right)$ & $4,225^{\mathrm{a}}$ & $3,715^{\mathrm{b}}$ & $4,314^{\mathrm{a}}$ & $3,673^{\mathrm{b}}$ & 74.93 & 0.7544 & 0.0001 & 0.3802 \\
\hline Albumen height (mm) & $6.90^{\mathrm{a}}$ & $6.35^{\mathrm{b}}$ & $7.01^{\mathrm{a}}$ & $6.10^{\mathrm{c}}$ & 0.07 & 0.3368 & 0.0001 & 0.0145 \\
\hline Haugh unit (score) & $81.15^{\mathrm{a}}$ & $77.73^{\mathrm{b}}$ & $82.13^{\mathrm{a}}$ & $75.50^{\mathrm{c}}$ & 0.55 & 0.2247 & 0.0001 & 0.0029 \\
\hline Yolk color (score) & $2.98^{\mathrm{d}}$ & $3.67^{\mathrm{c}}$ & $4.91^{\mathrm{b}}$ & $5.90^{\mathrm{a}}$ & 0.06 & 0.0001 & 0.0001 & 0.0280 \\
\hline
\end{tabular}

a,b,c,d Values with the different superscript are significantly different.

traits, excluding albumen height, Haugh unit, and yolk color $(\mathrm{p}<0.05)$.

The egg shape index values for eggs from white layers reared in an organic system was higher than that of eggs from white layers reared in a cage system, while no differences were observed in the egg shape index values for brown hens regardless of rearing system. These results are inconsistent with indication of Clerici et al. (2006) who reported no differences in the egg shape index values for eggs from layers reared in an organic or conventional system.

The egg shell thickness and shell breaking strength of eggs from white laying hens were higher than that of eggs from brown layer hens in both rearing systems. Eggs from layers in the organic system had an increased egg shell thickness as compared to eggs from layers in the conventional system. The findings from this present experiment agree with other studies (Rizzi et al., 2006; Mugnai et al., 2009) reporting that organic eggs have thicker egg shells as compared to conventional eggs. Ingestion of tiny stones and the hens' direct exposure to sunlight in the outdoor area to promote mineral metabolism, possibly leading to the augmentation of minerals in the shell, are potential reasons for the thicker and heavier shell structure in organic eggs (Rizzi et al., 2006). While several earlier works confirmed our findings (Clerici et al., 2006), others showed contradictory results (Minelli et al., 2007; Rossi, 2007).

The albumen height and Haugh unit of eggs from white layers was higher than that of eggs from brown layers both rearing system. Eggs from brown layers in the organic rearing system had increased albumen height (from 6.10 to 6.35) and Haugh unit (from 75.50 to 77.73) as compared to eggs from brown layers in the conventional rearing system. In contrast, no differences were observed in these characteristics for eggs from white layers from either rearing system. Our results are in accordance with the findings of the Minelli et al. (2007) who reported deterioration in the Haugh unit for eggs from brown layers presumably due to an alteration in albumen $\mathrm{pH}$ that might have been driven by the higher concentration of ammonia in the conventional cage system.

Indeed, brown hens reared in an organic system showed vigorous foraging activity in the yard in addition to the extra $2 \mathrm{~g}$ daily feed intake as compared to brown hens in cages. Consequently, a logical assumption would indicate that organic brown hens might have ingested more protein via grass residue, worms, and insects in the outdoor area. Hence, the extra cumulative nutrient intake might remarkably promote albumen quality in organically reared brown hens. Yet, no improvement was seen in the albumen quality of eggs from the white genotype.

The yolk color score that determinates the yellowness of the egg yolk was higher in eggs from brown hens as compared to eggs from white hens reared in both systems. The yolk color score for eggs from both white and brown hens reared in the organic system was inferior to their eggs produced by their counterparts reared in cages. This was also true for eggs from organically reared hens with no available grass in the outdoor area during the summer season (Mugnai et al., 2009). The authors concluded that birds used the in-feed carotenoids to protect themselves from solar irradiation in association with their biological protective actions. From another point of view, since carotenoids were known to provide a stronger immune response (Tengerdy et al., 1990; Moller et al., 2000), they might have been directed to support the immune system rather than being deposited in the egg yolk in cases where hens were directly exposed to sunlight as was experienced in this study. The higher yellowness in eggs from hens in cages is related to the presence of synthetic colorants in the conventional feed (Rossi, 2007).

Effects of rearing system and hen genotype on egg components, protein content, and yolk cholesterol concentration are presented in Table 6, and their influences on fatty acid composition of whole egg is given in Table 7.

Rearing system significantly affected albumen, yolk, and shell ratio, and significant differences in albumen and shell ratios were determined among genotypes $(\mathrm{p}<0.01)$. Albumen ratio showed different tendencies in each rearing 
Table 6. Effects of rearing systems on egg components, egg protein content and egg yolk cholesterol concentration of two layer strains

\begin{tabular}{|c|c|c|c|c|c|c|c|c|}
\hline \multirow{2}{*}{ Egg component } & \multicolumn{2}{|c|}{ Organic } & \multicolumn{2}{|c|}{ Conventional } & \multirow{2}{*}{ SEM } & \multicolumn{3}{|c|}{$\mathrm{p}$ value } \\
\hline & White & Brown & White & Brown & & Rearing & Genotype & $\mathrm{R} \times \mathrm{G}$ \\
\hline Egg weight (g) & 65.07 & 64.94 & 65.38 & 64.31 & 0.34 & 0.6441 & 0.0861 & 0.1747 \\
\hline Albumen (\%) & $62.56^{\mathrm{b}}$ & $63.65^{\mathrm{a}}$ & $63.39^{\mathrm{a}}$ & $63.78^{\mathrm{a}}$ & 0.16 & 0.0028 & 0.0001 & 0.0318 \\
\hline Yolk (\%) & $27.29^{\mathrm{a}}$ & $26.93^{\mathrm{ab}}$ & $26.73^{\mathrm{b}}$ & $26.90^{\mathrm{ab}}$ & 0.015 & 0.0455 & 0.5228 & 0.0849 \\
\hline Shell (\%) & $10.58^{\mathrm{a}}$ & $9.77^{\mathrm{c}}$ & $10.36^{\mathrm{b}}$ & $9.63^{\mathrm{c}}$ & 0.05 & 0.0003 & 0.0001 & 0.4095 \\
\hline Cholesterol (mg/g) & 14.17 & 14.83 & 14.90 & 14.08 & 1.12 & 0.9612 & 0.7416 & 0.1962 \\
\hline Protein $(\%)$ & $13.19^{\mathrm{ab}}$ & $13.32^{\mathrm{a}}$ & $12.85^{\mathrm{b}}$ & $13.32^{\mathrm{a}}$ & 0.11 & 0.1235 & 0.0110 & 0.1337 \\
\hline
\end{tabular}

$\overline{\mathrm{a}, \mathrm{b}, \mathrm{c}}$ Values with the different superscript are significantly different .

system signifying a rearing system $\times$ genotype interaction $(\mathrm{p}<0.05)$. Our result that albumen ratio was not affected by rearing system was in accordance with the findings of the previous studies in which brown layers were used (Van Den Brand et al., 2004; Cerolini et al., 2005; Rizzi et al., 2006). However, in contrast Cherian et al. (2002) found that white eggs in organic system had higher albumen ratio than those produced in a conventional cage system.

Yolk ratio was not affected by genotype but it differed with respect to rearing type. In accordance with our findings, Cerolini et al. (2005), Rizzi et al. (2006), and Rossi (2007) reported that egg yolk ratio of white eggs produced in an organic rearing system was higher than those in cages. The higher percentage of egg yolk was attributed to dietary intake of grass and insects by Rizzi et al. (2006). Both the rearing system and hen genotype substantially affected the shell ratio $(p<0.01)$. Shell ratio of white eggs in organic system and conventional system was significantly higher than in brown eggs $(\mathrm{p}<0.05)$.

The shell ratio was found to be high in the organic system as compared to cage housing in our study $(\mathrm{p}<0.01)$. This determination is consistent with our finding of egg shell thickness. Different from our results, some previous studies (Cherian et al., 2002; Van Den Brand et al., 2004; Cerolini et al., 2005) reported that rearing system has no effect on egg shell ratio.

The influence of rearing system on egg protein content was insignificant, whereas a significant effect was found with genotype $(\mathrm{p}<0.05)$. Protein content was higher in brown eggs than in white eggs $(\mathrm{p}<0.05)$. We obtained

Table 7. Effects of rearing systems on egg fatty acid composition of two layer strains

\begin{tabular}{|c|c|c|c|c|c|c|c|c|}
\hline \multirow{2}{*}{ Fatty acid (\%) } & \multicolumn{2}{|c|}{ Organic } & \multicolumn{2}{|c|}{ Conventional } & \multirow{2}{*}{ SEM } & \multicolumn{3}{|c|}{$\mathrm{p}$ value } \\
\hline & White & Brown & White & Brown & & Rearing & Genotype & $\mathrm{R} \times \mathrm{G}$ \\
\hline Myristic C14:0 & 0.33 & 0.25 & 0.32 & 0.30 & 0.04 & 0.6448 & 0.2876 & 0.4280 \\
\hline Palmitic C16:0 & 25.33 & 25.39 & 25.24 & 24.86 & 0.33 & 0.3633 & 0.6250 & 0.5169 \\
\hline Margaric C17:0 & 0.20 & 0.17 & 0.14 & 0.17 & 0.02 & 0.1998 & 0.9496 & 0.3460 \\
\hline Stearic C18:0 & $8.71^{\mathrm{a}}$ & $7.83^{\mathrm{b}}$ & $9.06^{\mathrm{a}}$ & $7.1^{\mathrm{c}}$ & 0.22 & 0.3980 & 0.0001 & 0.0237 \\
\hline Total SFA & $34.21^{\mathrm{ab}}$ & $33.82^{\mathrm{b}}$ & $34.87^{\mathrm{a}}$ & $32.54^{\mathrm{c}}$ & 0.35 & 0.3959 & 0.0004 & 0.0095 \\
\hline Heptadecenoic C17:1 & 0.22 & 0.08 & 0.07 & 0.12 & 0.05 & 0.3737 & 0.4045 & 0.1142 \\
\hline Palmitoleic C16:1 & $3.01^{\mathrm{b}}$ & $3.34^{\mathrm{a}}$ & $3.07^{\mathrm{b}}$ & $3.45^{\mathrm{a}}$ & 0.09 & 0.3405 & 0.0004 & 0.7868 \\
\hline Oleic C18:1 & 39.92 & 39.63 & 40.35 & 40.00 & 0.64 & 0.5356 & 0.6217 & 0.9643 \\
\hline Eicosenoic C20:1 & 0.18 & 0.17 & 0.15 & 0.18 & 0.02 & 0.7179 & 0.7544 & 0.4566 \\
\hline Miristoleic C14:1 & 0.02 & 0.02 & 0.02 & 0.04 & 0.007 & 0.1925 & 0.2841 & 0.2087 \\
\hline Total MUFA & 43.59 & 43.28 & 43.7 & 43.83 & 0.62 & 0.5205 & 0.9554 & 0.7940 \\
\hline Linoleic C18:2 & 19.50 & 20.05 & 18.47 & 19.86 & 0.51 & 0.2319 & 0.0599 & 0.4002 \\
\hline Linolenic C18:3 & $0.81^{\mathrm{b}}$ & $0.93^{\mathrm{b}}$ & $0.90^{\mathrm{b}}$ & $1.15^{\mathrm{a}}$ & 0.04 & 0.0012 & 0.0002 & 0.1759 \\
\hline Arachidonic C20:4 & 0.14 & 0.07 & 0.13 & 0.12 & 0.02 & 0.5166 & 0.1151 & 0.2163 \\
\hline DHA C22:6 & 0.58 & 0.52 & 0.57 & 0.61 & 0.03 & 0.1717 & 0.7819 & 0.1376 \\
\hline Total PUFA & 21.01 & 21.44 & 20.04 & 21.7 & 0.55 & 0.5158 & 0.0610 & 0.2662 \\
\hline Other & 1.25 & 1.52 & 1.41 & 1.37 & 0.13 & 0.9514 & 0.4121 & 0.2678 \\
\hline Omega-6 & 19.66 & 20.13 & 18.61 & 19.99 & 0.51 & 0.2417 & 0.0724 & 0.3693 \\
\hline Omega-3 & $1.34^{\mathrm{b}}$ & $1.31^{\mathrm{b}}$ & $1.43^{\mathrm{a}}$ & $1.72^{\mathrm{a}}$ & 0.06 & 0.0004 & 0.0484 & 0.0171 \\
\hline$n-6: n-3$ & $14.28^{\mathrm{b}}$ & $15.56^{\mathrm{a}}$ & $12.53^{\mathrm{c}}$ & $11.95^{\mathrm{c}}$ & 0.43 & 0.0001 & 0.4318 & 0.0407 \\
\hline PUFA:SFA & $0.59^{\mathrm{b}}$ & $0.63^{\mathrm{ab}}$ & $0.57^{\mathrm{b}}$ & $0.68^{\mathrm{a}}$ & 0.03 & 0.5801 & 0.0060 & 0.1575 \\
\hline
\end{tabular}

\footnotetext{
$\overline{a, b, c}$ Values with the different superscript are significantly different.
} 
similar results as those of Rizzi et al. (2006) and Rossi (2007) indicating that albumen and yolk protein ratios were not different under organic and conventional systems, whereas our results differ from those of Minelli et al. (2007) who reported that yolk protein ratio was higher in the organic system. It is speculated that the higher protein ratio in brown eggs as compared with white eggs in this study might have resulted from the extra daily feed intake by the brown hens while yielding less egg mass as compared to white layers.

Neither rearing system nor hen strain modified egg yolk cholesterol concentration ( $p>0.05$ ). Our results confirm the results of many previous reports (Cerolini et al., 2005; Rizzi et al., 2006; Rossi, 2007; Zemkova et al., 2007) in that rearing system and genotype had no effect on egg yolk cholesterol concentration, but were dissimilar with the findings of Minelli et al. (2007) who indicated that egg yolk cholesterol concentration was lower in the conventional system.

\section{Fatty acid profile of egg yolk}

There were significant differences between the organic and conventional rearing system with respect to linolenic acid, total omega-3 fatty acid content, and the omega 6 /omega 3 ratio (Table 7). Different from the pattern observed with the housing system, relatively more influence on egg fatty acid composition was observed in response to bird genotype.

Rearing system by genotype interactions regarding stearic acid and total saturated fatty acid contents were found to be significant. Significant reductions were determined in stearic acid and total SFA contents in brown eggs with regard to alteration in housing system, whereas an opposite trend was observed in the white eggs.

Our findings are partially in agreement with the reports of some other researchers (Cherian et al., 2002; Rizzi et al., 2006) who declared that fatty acid compositions of eggs in organic system was not significantly different from those in the conventional system. Rossi (2007) also found no difference in fatty acid composition of eggs obtained in organic and conventional systems except for total SFA, but reported higher SFA content in organic eggs as the similar was case in brown eggs in our study. Another report by Samman et al. (2009) confirms our findings concerning proportion of stearic acid in brown organic eggs.
Eggs produced in the organic system were poor in yolk omega-3 content when compared to eggs laid by hens reared in the conventional system. Significant genotype by rearing system interaction was also observed for egg yolk omega-3 concentration and n-6:n-3 ratio. Even though the n-6:n-3 ratio was higher in organic brown eggs compared to white ones, this was not the case in the conventional system. Similar to our results, Cerolini et al. (2005) reported that omega-3 fatty acid content was significantly lower in organic eggs compared to eggs in other rearing systems. They concluded that this difference might have been resulted from the feed quality but not from rearing system. Our results differ from the results of Lopez-Bote et al. (1998) who reported that eggs in the free range system had higher omega-3 (2.6 fold) and lower omega-6 contents compared to those in the conventional system. The author attributed their findings to the fully available pasture composed of several species of grass (mainly Italian ryegrass, Lolium perenne), legumes, and herbs which are known to be rich in omega-3 and low omega- 6 fatty acid contents. However, in our study, since the hens had rapidly depleted the pasture during the pullet rearing period, no vegetation was available during the egg laying phase. Therefore, such a discrepancy between the results may be explained by the unavailability of the vegetation and consumption in the outdoor area. It is interesting to note that the organic eggs had a lower omega-3 level when compared with the conventional eggs (Table 7) despite the fact that hens in the organic system had been fed with diets rich in omega-3 content (Table 2). We speculated that hens in the organic system were usually exposed to different environmental factors compared with conventional cage barns; hence, they might have utilized omega-3 as an essential nutrient in order to support their immune system against external stimulations rather than depositing it in the egg. Even though the EU directive demands covering pasture in the outdoor area, it is obvious that continuous and vigorous foraging activity can limit grass intake all along during the laying period. Therefore, hens could not benefit from pasture as a n-3 fatty acid source, as was experienced under the free range conditions in our study.

\section{Immune response}

Mean serum IBV, IBD and NDV titers of hens are illustrated in Table 8 . While the rearing system significantly

Table 8. Effects of rearing systems on immune response of two layer strains

\begin{tabular}{|c|c|c|c|c|c|c|c|c|}
\hline & \multicolumn{2}{|c|}{ Organic } & \multicolumn{2}{|c|}{ Conventional } & \multirow{2}{*}{ SEM } & \multicolumn{3}{|c|}{$\mathrm{p}$ value } \\
\hline & White & Brown & White & Brown & & Rearing & Genotype & $\mathrm{R} \times \mathrm{G}$ \\
\hline IBV & $12,325^{\mathrm{b}}$ & $14,707^{\mathrm{a}}$ & $12,147^{\mathrm{b}}$ & $15,018^{\mathrm{a}}$ & 641 & 0.9181 & 0.0001 & 0.7077 \\
\hline IBD & 5,386 & 6,691 & 7,196 & 7,632 & 1,024 & 0.1892 & 0.4041 & 0.6769 \\
\hline NDV & $12,311^{\mathrm{a}}$ & $10,513^{\mathrm{ab}}$ & $9,556^{\mathrm{b}}$ & $9,541^{\mathrm{b}}$ & 664 & 0.0065 & 0.1768 & 0.1838 \\
\hline
\end{tabular}

${ }^{\mathrm{a}, \mathrm{b}}$ Values with the different superscript are significantly different. 
affected the serum NDV titers $(\mathrm{p}<0.05)$, that did not influence the specific immune response of hens measured as serum IBV and IBD titers. Mean serum NDV titer of hens was higher in organic system compared to that value in cages. The serum IBV titers of brown laying hens were significantly higher than that of white hens $(\mathrm{p}<0.01)$. Some earlier studies have shown that humoral immune response can be affected by rearing system (Dohms, 1991; Arbona et al., 2011) and breed and age of the birds (Regnier et al., 1980) in laying hens while there is hardly any publication available regarding organic rearing system.

\section{CONCLUSIONS}

In conclusion, both rearing system and hen genotype had considerable effects on some of the performance parameters and egg quality characteristics examined in this study. Commercial white hens had a higher egg production rate and produced eggs with better albumen and egg shell quality than the native brown strain. Nevertheless, the brown strain yielded more cumulative eggs as a result of superior livability. Better survival of the native brown breed is conclusive and indicative of the importance of the hen breed in terms of organic production systems. Due to the limited availability of forage within the current study, the effect of forage consumption on egg quality in the organic housing conditions was limited. Further research is needed to investigate the dietary influences of pasture composition and herbal intake on nutrient utilization and egg quality in laying hens.

\section{ACKNOWLEDGEMENT}

This project was supported by Turkish Ministry of Agriculture and Rural Affairs, Project No: TAGEM/HAYSÜD/06/12/01/01.

\section{REFERENCES}

Arbona, V., K. E. Anderson and J. B. Hoffman. 2011. A comparison of humoral immune function in response to a killed newcastle's vaccine challenge in caged vs. free-range Hy-line brown layers. Int. J. Poult. Sci. 10(4):315-319.

Anonymous. 1991. Animal feed-determination of metabolizable energy (chemical method). Turkish Standards Institute (TSE), Publ. No. 9610:1-32.

AOAC. 1995. Official methods of analysis (16th ed.). Association of Official Analytical Chemists, Inc., Washington DC, USA.

Basmacioğlu, H. and M. Ergül. 2005. Research on the factors affecting cholesterol content and some other characteristics of eggs in laying hens. Turk. J. Vet. Anim. Sci. 29:157-164.

Bestman, M. W. P. and J. P. Wagenaar. 2003. Farm level factors associated with feather pecking in organic laying hens. Livest. Prod. Sci. 80:133-140.

Castellini, C., C. Mugnai, A. Dal Bosco, M. Palozzo and S. Scuota.
2004. Aspetti comportamentali, prestazioni produttive e qualita dell'uovo in galinle allevate con il metodo biologico. Riv. Avicolt. 3(5-6):41-44.

Cerolini, S., L. Zaniboni and R. La Cognata. 2005. Lipid characteristics in eggs produced in different housing systems. Ital. J. Anim. Sci. 4:520.

Cherian, G., T. B. Holsonbake and M. P. Goeger, 2002. Fatty acid composition and egg components of specialty eggs. Poult. Sci. 81:30-33.

Clerici, F., E. Casiraghi, A. Hidalgo and M. Rossi. 2006. Evaluation of eggshell quality characteristics in relation to the housing system of laying hens. XII. Eur. Poult. Conf. 10-14 September 2006. Verona-Italy.

Danish Poultry Council. 2000. Annual report. The Danish Poultry Council. Trommesalen, Copenhagan, 228 page.

Dohms, J. M. 1991. Stress-mechanisms of immunosuppression. Vet. Immunol. Immunophysiol. 30:89-109.

EU (European Union). Directive 1999/74/EC, July 19, 1999, Council. 1999. Laying down minimum standards for the protection of laying hens. Official Journal of the European Communities L203:53-57.

EU (European Union). Directive 834/2007/EC, June 28, 2007, Council. 2007. Organic production and labelling of organic products. Official Journal of the European Communities L189:1-23.

IUPAC. 1987. Standard methods for the analysis of oils, fats and Derivatives. 7 th edition. Prepared for publication by A. Dieffenbacher and W. D. Pooklington. International Union of Pure and Applied Chemistry. Oxford Blackwell Scientific Publications.

Kouba, M. 2003. Quality of organic animal products. Livest. Prod. Sci. 80:33-40.

Lampkin, N. 1997. Organic poultry production. Final report to MAFF. CSA 3699. University of Wales.

Lopez-Bote, C. J., R. S. Arias, A. I. Rey, A. Castano, B. Isabel and J. Thos. 1998. Effect of free range feeding on n-3 fatty acid and alpha-tocopherol content and oxidative stability of eggs. Anim. Feed. Sci. Technol. 72:33-40.

Minelli, G., F. Sirri, E. Folegatti, A. Meluzzi and A. Franchini. 2007. Egg quality traits of laying hens reared in organic and conventional systems. Ital. J. Anim. Sci. 6:728-730.

Moller, A. P., C. Biard, J. D. Blount, D. C. Houston, P. Ninni, N. Saino and P.F. Surai. 2000. Carotenoid-dependent-signals: indicator of foraging efficiency, immunocompetence or detoxification ability?. Avian Poult. Biol. Rev. 11:137-159.

Mugnai, C., A. Dal Bosco and C. Castellini. 2009. Effects of rearing system and season on the performance and egg charasteristics of Ancona laying hens. Ital. J. Anim. Sci. 8:175188.

Novak, C., H. Yakout and S. Scheideler. 2004. The combined effects of dietary lysine and total sulfur amino acid level on egg production parameters and egg components in Dekalb Delta laying hens. Poult. Sci. 83:977-984

Rizzi, C. and G. M. Chiericato. 2005. Organic farming production. Effect of age on the productive yield and egg quality of hens of two commercial hybrid lines and two local breeds. Ital. J. Anim. Sci.4 (Suppl. 3):160-162.

Rizzi, L., G. Simioli, G. Martelli, R. Paganelli and L. Sardi. 2006. Effects of organic farming on egg quality and welfare of laying 
hens. XII. Eur. Poult. Conf. 10-14 September 2006. VeronaItaly.

Regnier, J. A., Kelley, K. W. and Gaskins C. T.. 1980. Acute thermal stressors and synthesis of antibodies in chickens. Poult. Sci. 59:985-990.

Rossi, M. 2007. Influence of the laying hen housing systems on table egg characteristics. Proceedings of the XVIII ${ }^{\mathrm{TM}}$ Eur. Symp. Quality Poult. Meat. XII ${ }^{\text {th }}$ Eur. Symp. Quality Eggs and Egg Prod. Prague.

Roush, W. B. 1981. T 159 calculator program for Haugh unit calculation. Poult. Sci. 60:1086-1088.

Samman, S., F. P. Kung, L. M. Carter, M. J. Foster, Z. I. Ahmad, J. L. Phuyal and P. Petocz. 2009. Fatty acid composition of certified organic, conventional and omega-3 eggs. Food Chem. 116:911-914.

SAS user's guide, statistics edition.1995. SAS Institute Inc., NC, USA.
Shashidhara, R. G. and G. Dewegowda. 2003. Effect of dietary mannan oligosaccharide on broiler breeder production traits and immunity. Poult. Sci. 82:1319-1325.

Şekeroğlu, A. and M. Sarıca. 2005. The effects of free range system on egg productions and egg quality of brown and white layer genotypes. J. Poult. Res. 6(1):10-16.

Tengerdy, R. P., N. G. Lacetera and C. F. Nockels. 1990. Effects of $\beta$-carotene on disease protection and humoral immunity in chickens. Avian Dis. 34:848-854.

Van Den Brand, H., H. K. Parmantier and B. Kemp. 2004. Effect of housing system (outdoor vs. cages) and age of laying hens on egg characteristics. Br. Poult. Sci. 45:745-752.

Zemkova, L., J. Simeonovova, M. Lichovnikova and K. Somerlikova. 2007. The effects of housing systems and age of hens on the weight and cholesterol concentration of the egg. Czech. J. Anim. Sci. 52:110-115. 